\title{
Differences in sit-to-stand, standing sway and stairs between community- dwelling fallers and non-fallers: A review of the literature.
}

\begin{abstract}
Background: Falls are extremely common and have a significant impact on an individual's wellbeing. Individuals who fall often display altered function however to date no synthesis pertaining to the nature of these alterations is available. Such information is important to guide assessment and management strategies.

Objectives: To appraise and synthesize literature directly comparing communitydwelling elderly fallers with non-fallers across tasks of sit-to-stand, standing postural sway with eyes open and stairs.

Methods: A structured search of Medline, SPORTDicuss, Science Citation Index, OAIster, CINAHL, Academic Search Complete, Science Direct and Scopus databases was conducted in July 2017. Articles were limited to peer-reviewed in the English language comparing elderly community-dwelling fallers to non-fallers.

Results: Eight articles were included relating to sit-to-stand, seven for postural sway and one for stairs. Fallers stood from sitting significantly slower, with lower linear velocity and maximum power than non-fallers. This was best observed when arms were not used and when the stand was attempted as quickly as possible. Fallers displayed significantly greater sway path lengths and centre of pressure velocity compared with non-fallers, but only when assessed in narrow or near narrow stance. Fallers used less force during stepping up compared with non-fallers. Conclusion: The findings of this review suggest that activities of daily living may be able to discriminate between fallers and non-fallers therefore offering the potential for community based assessment of fallers.
\end{abstract}




\section{Introduction}

Globally falls are the second largest cause of accidental injurious deaths and the most common cause in individuals over the age of $65 .{ }^{1,2}$ Non-fatal falls are extremely common and have a significant impact on a person's well-being, often resulting in pain, injury and loss of confidence and independence. ${ }^{2,3}$ The National Institute for Health and Care Excellence (NICE) identify people aged 65 and over being at the highest risk of falls with approximately $30 \%$ of over 65 s falling at least once a year.

${ }^{4,5}$ Currently $18 \%$ of the UK population is within this age bracket with this percentage projected to increase continuously over the next 30 years. ${ }^{6}$ As well as the detrimental effects falling can have on a person's health and well-being they also have a significant financial impact, estimated to be costing the NHS over $£ 2.3$ billion each year. $^{4}$

Falls risk and falls management is known to be multifactorial and often involves rehabilitation aimed to improve physical function. In order for targeted rehabilitation to be developed a clear identification of impairments is required. Currently a multitude of tests have been proposed to differentiate fallers from nonfallers. Tests such as functional reach ${ }^{7}$ or Berg balance assessment ${ }^{8}$ provide data limited to a single point in time, and require subjective interpretation. Furthermore they require the individual to conduct a specific set of balance tests and therefore do not relate to usual daily function. Moreover although these tests may be clinically useful they do not provide information relating to specific biomechanical impairments. Observational clinical tests provide information relating to a person's 
ability to perform those tasks and generally rely on a practitioner's observational acuity to identify the area of limitation.

More recently prospective studies have proposed the use of monitoring daily activities through wearable sensors or camera-based technology. In addition similar technologies have been used to identify falls events. ${ }^{9,10}$ Such methods could offer an attractive future opportunity to conduct assessments of daily tasks to identify impairments in physical function related to falls. In order to achieve this a detailed understanding of how fallers differ in physical function during activities of daily living to non-fallers is required.

The aim of this literature review was to identify, appraise and synthesize the published evidence directly comparing community-dwelling elderly fallers with nonfallers across three common daily living tasks. These tasks are: standing from a seated position, postural control in two-legged standing and walking up and down stairs.

\section{Method}

\section{Search Strategy}

Three separate systematic searches of electronic databases (Medline, SPORTDicuss, Science Citation Index, OAIster, CINAHL, Academic Search Complete, Science Direct and Scopus) were conducted, each pertaining to a different functional task to be reviewed within this article: sit to stand (STS), using stairs and the postural sway associated with static double leg stance. These tasks were selected as they represent activities that would normally be performed daily within the home. All searches were 
conducted in July 2017. The Boolean search terms used for each search can be seen in table 1. The searches were limited to peer-reviewed, English language journal articles.

Table 1

Duplicates were removed automatically by the search tool. The remaining articles were reviewed based on their titles and abstracts against the inclusion and exclusion criteria. Articles not excluded were retrieved and the full text used to determine their suitability. The reference lists of eligible articles were then examined for any further studies that could be included. A flow diagram outlining this process for each search can be seen in figures $1,2 \& 3$. Two authors independently completed the data extraction and review process with any areas of uncertainty resolved by consensus.

Figures 1-3

\section{Inclusion and Exclusion Criteria}

The minimum age for participants was set at 65 , as this is the population at highest risk of falling ${ }^{4}$ and widely accepted in developed countries as a definition of 'elderly.' ${ }^{11}$ Where a minimum age criteria was not specified in an article it was included if the mean age minus two standard deviations was 65 or greater. All participants were required to be community dwelling. The articles needed to directly compare elderly fallers to elderly non-fallers in either a retrospective or crosssectional design. Reviews, conference proceedings and discussion pieces were excluded, as were purely prospective studies. Articles concerning treatment or rehabilitation where data could not be extracted were also excluded as were those 
investigating falls in balance impairing conditions such as stroke or Parkinson's disease.

\section{Quality Appraisal and Data Extraction}

Data pertaining to specific areas of methodology and results were extracted and can be seen in tables $2,3 \& 4$. As the focus of this review was on the comparison of performance of daily tasks between fallers and non-fallers, data extraction concentrated on the biomechanical performance metrics and the measurement of such tasks. This information should serve to inform clinicians as the likely physical impairments of daily living which may serve as rehabilitation targets or to help identify fallers, where self-disclosure isn't forthcoming. The methodological quality of the articles was assessed using the 'National Institutes of Health's Quality Assessment Tool for Observational Cohort and Cross-sectional Studies' ${ }^{12}$ as seen in table 5. This tool was selected following the recommendations of Wardle \& Steel ${ }^{13}$ for critically appraising the quality of cohort and cross-sectional studies within a systematic review. This tool consists of 14 questions for which an article can achieve a yes, no, cannot determine, not applicable or not reported response.

\section{Results}

\section{Study characteristics}

Sit to Stand 
Eight relevant articles were identified from the search process related to sit-to-stand (STS). ${ }^{14-21}$ These studies consisted of seven retrospective cohort studies ${ }^{14-19,21}$ and one combined retrospective and prospective cohort study ${ }^{20}$ and were all published between 2010 and 2017. A data extraction table for these eight studies can be seen in table 2. The studies ranged in number of participants from $38-212$ with a total of 698 participants across all studies consisting of 330 fallers and 368 non-fallers. Mean age of participants ranged from 70-81 years old and between $63-85 \%$ were female. Falls history was defined as one or more fall (not trip or slip) in the previous 12 months. Two studies used the outcome measure of duration taken to complete a five time sit-to-stand (5TSTS), ${ }^{14,15}$ five investigated a single STS, ${ }^{14,18-21}$ two explored sit to walk ${ }^{16,17}$ and one, walk to sit. ${ }^{17} \mathrm{~A}$ wide variety of techniques and equipment were used to assess the characteristics of STS including force plates, ${ }^{14,18-20}$ a stop watch ${ }^{15}$ or kinetic motion camera, ${ }^{15}$ a bespoke pulley system, ${ }^{21}$ and a combined accelerometer and gyroscope either worn as a pendent around the neck ${ }^{16}$ or on a belt around the low back. ${ }^{17}$

\section{Postural Sway}

Seven relevant articles were identified from this specific search. ${ }^{18,22-27}$ These studies consisted of six retrospective cohort studies ${ }^{18,22,24-27}$ and one combined prospective and retrospective cohort study ${ }^{23}$ and were all published between 2004 and 2016. A data extraction table for these studies can be seen in table 3 . The studies ranged in number of participants from $23-212$ with a total of 646 participants across all studies consisting of 240 fallers and 406 non-fallers. Mean age of participants ranged from 
78-85 years old and between 58-90\% were female. Falls history ranged from one fall in the previous 12 months to 2 or more falls in previous 6 months. Six articles used force plates to measure their participants' postural sway ${ }^{18,23-27}$ and one article used a marked vest and a camera. ${ }^{22}$ There was relatively large heterogeneity between studies regarding foot positioning of participants with generally limited description throughout.

\section{Stairs}

The initial search yielded 308 articles after exact duplicates were removed. Of these 267 were excluded based on their title or abstract. After reviewing the full texts of the 41 remaining articles against the inclusion and exclusion criteria, only one article ${ }^{18}$ was appropriate for inclusion. On review of this article's reference list no further articles were identified for inclusion. The data extraction table for this article can be seen in table 4. This article consisted of 212 participants, 99 fallers and 113 nonfallers. Mean age of participants was $78 \%$ and $85 \%$ were female. Falls history was defined as 2 or more falls in the previous 6 months. They assessed participants using a force plate while they stepped onto and down from a step.

\section{Quality}

Overall study quality was rated as a percentage of relevant items on the appraisal tool. Articles concerning sit-to-stand ranged from having $33 \%$ of items present to $83 \%$ of items present. Regarding postural sway articles ranged from $40 \%$ to $73 \%$ of items present and for stairs $44 \%$ of items present. The quality appraisal review identified 
common threats to the validity within the studies. None of the studies focusing on STS or stairs, and only two of the seven postural control studies gave justification for their chosen sample size. Justification of sample size is a way to determine if the study has been correctly powered to find a difference in the key outcome variable. Under powering a study could prevent identification of significant differences between fallers and non-fallers, if one is to be found, and can therefore lead to erroneous conclusions being drawn from the data.

All but two of the articles analyzed in this review did not measure the exposure of interest prior to the outcomes or allow an appropriate time frame for the outcome to be demonstrated following the exposure. The first of these is important as it allows the researcher to know if the outcome was present prior to the exposure or whether it has arisen following it; regarding the aim of this study, if a person had differences in their STS or other functional task prior to falling or only since. Allowing a suitable time frame is important for observational studies to be able to fully analyze the relationship between the exposure and outcome.

The majority of articles included in this review were retrospective cohort studies and therefore did not meet these criteria due to the inherent limitations in this experimental design. This means that it is difficult to determine from the studies if any differences in the measures applied to and compared with fallers and non-fallers were present prior to participants falling. Eleven articles failed to assess different levels of exposure in relation to the outcomes. Understanding the potential 'dose response relationship' multiple falls may produce is important but is not the focus of this review, which is to identify differences between those who have fallen and those who have not. Therefore dose response is beyond the scope of the current review; 
meaning the validity of the results in the studies reviewed has not been affected by this methodological limitation.

Only one of the articles reviewed reported whether outcome assessors were blinded to group allocation. Blinding is generally considered to be important in controlled studies to avoid the potential for operator bias. However, this was commonly overcome in the articles reviewed by automation of the outcome measure assessment, i.e. computer programs to collect data. Although many of the articles reviewed with regards to STS identified potential baseline confounding variables several articles either did not report these or state whether or not these were adjusted for if they were identified. Differences in characteristics such as age or gender may result in differences between groups which can be attributed to these variables as opposed to whether they are a faller or not.

Over half of the postural control studies failed to specify where the participants were from, except for being community dwelling. Defining the study population is important as it can give rise to factors that may explain variance in results within the study or between studies. This gap in description may not strongly affect the actual results of the study but will limit the extrapolation of its data to a wider population.

Despite these limitations it is possible to draw some summaries pertaining to the aims of this review. Regarding sit-to-stand, fallers take longer to complete STS and this is evident regardless of how this is timed (i.e. STS or 5STS). However it has been shown that individual movement phases in STS were no more discriminative than the total movement. Moreover, individuals who have fallen display lower linear velocity during STS and reduced maximum power output during STS. It is unclear, 
due to conflicting findings, whether fallers generate lower vertical ground reaction force.

It is worthy of note that one study was in contrast to the findings outlined above. This study did not utilize a STS protocol instead required the participants to sit to walk. This eliminates the necessity to control for anterior propulsion of the centre of mass and the requirement to decelerate this to stationary on completion of the STS, as seen in the other studies. This may explain why this study is in contraction to the bulk of others investigating STS.

Regarding postural control fallers demonstrate greater CoP velocity and greater CoP path length but only in stance with feet close together (narrow stance). Occasionally these differences are evident in normal stance but not always. Furthermore there are conflicting findings pertaining to greater sway displacement in AP and ML directions, CoP ML path lengths and larger area of CoP.

Regarding stairs just one study demonstrated that fallers apply less force to the step during a step up, no such differences were evident during stepping down. 


\section{Discussion}

The aim of this review was to synthesize the evidence pertaining to the differences between community-dwelling elderly fallers and non-fallers. The heterogeneity of the studies demonstrated differences in overall quality, however no studies were removed on quality grounds as none were identified as fundamentally flawed. In order to fully understand why their remains areas of conflicting evidence and to be able to apply this knowledge to practice some additional discussion is required.

It is clear that the time taken to complete the task of sit to stand was different between fallers from non-fallers. This was a consistent finding across the three studies that investigated it. ${ }^{14-15,18}$ The magnitude of difference was greater during a single STS (32-44\%) ${ }^{14,18}$ compared to 5TSTS (14-24\%). ${ }^{14,15}$ This suggests that the performance over a shorter period is sufficient to identify this impairment in fallers. It is likely that these two tasks have different underlying constructs, with the single STS utilizing an explosive single motion requiring acceleration and power whereas 5TSTS requiring a level of power endurance to complete the task repeatedly. This result is counter-intuitive as it would be expected that having to perform the same task repeatedly, fatigue would result in a gradual divergence between groups. One explanation for this is that fallers may be more fearful or apprehensive of standing for the first time. In contrast when standing up multiple times, individual's confidence may increase and with it, the speed at which they perform the task. No studies have reported on whether the first STS took significantly longer than the fifth, but this $1^{\text {st }}: 5^{\text {th }}$ ratio might offer specific insights into this concept. 
The sub-sections of STS are believed to represent differing levels of challenge for an individual. The forward lean, propulsion-to-upright and standing phase require different muscle action, control of the centre of mass and perturbation challenges. ${ }^{14}$ Therefore it is possible that sub-sectioning STS may offer more insight into the impairment evident in fallers. Only one study explored the preparation phase, the rising phase and the stabilization phase and found a significant difference in the time taken to complete each of these various stages. ${ }^{14}$ As this was only assessed in one study it is not clear if such a finding is due to the sample used or indeed reflects a true overall increase in time taken to complete the whole task, regardless of sub-section. This may suggest a general, centrally controlled response to the task by which the nervous system 'chooses' to take longer over the whole task, providing more time to process the shifting centre of mass. Such generic 'down gearing' has been observed in other clinical conditions such as back pain. ${ }^{28,29}$ This suggests that the individual physiological element limiting the capacity of the sub-section (i.e. muscle power for the propulsive phase) is not the element limiting the task. A central control mechanism overrides this, choosing to take longer to complete tasks. However it could also be the case that each of the limiters for each of these sub-sections are impaired and thus the resultant increase to complete the sub-section relates to specific impairments in that sub-section. An example would be the propulsive phase limited by muscle power and the standing phase limited by impairments in response to centre of mass perturbation. If each underlying physiological construct for each sub-phase were impaired in the faller, then each sub-section would result in a greater time to complete as seen in the study in this review.

The findings from this study suggest that time taken to complete STS (and single 5TSTS) were able to identify difference in fallers and non-fallers, however the 
additional value of the breakdown of specific sub-sections requires further exploration.

Chair height is believed to affect a person's ability to complete a STS and a variety of heights were used in the studies. Some studies chose a fixed chair height, commonly $45 \mathrm{~cm} .{ }^{14-16,20}$ This standardized approach fails to accommodate for the variety of heights of participants resulting in greater or lesser knee flexion angles. Others ${ }^{14,21}$ accommodated participant anthropometrics using adjustable height chairs; aiming to achieve approximate knee flexion angles of $90^{\circ}$. However, other studies failed to adequately describe chair height. It is likely that the lower the chair height or greater the knee flexion angle, the greater the challenge to the individual which, in this case, may demonstrate greater differences between fallers and non-fallers. The findings of this review illustrate that for time taken to complete a STS or 5TSTS was greater in fallers, regardless of chair height. This suggests a pragmatic approach to chair selection is recommended for the assessment of STS and 5TSTS.

The addition of an arm push during STS would alter the complexity of the task by modifying the base of support and reducing the propulsion required from the leg musculature. The majority of studies ${ }^{14,15,18-21}$ identified this as a potential issue. For time taken to complete a STS or 5TSTS two studies requested arms across the chest, ${ }^{14,15}$ one instructed the participants not to use their arms ${ }^{18}$ and one did not mention this detail. ${ }^{16}$ Interestingly those studies identifying a significant difference in duration to complete STS all prevented the addition of the arms. The study in conflict to these results ${ }^{16}$ did not provide any details pertaining to use of arms. The crossed arm technique potentially represents an atypical movement pattern offering an additional challenge in terms of altering the location of the centre of mass, as well as increasing the challenge on the leg musculature and preventing righting reactions from the arms 
required for maintaining balance. It is possible that the additional demands result in divergence in performance between the two groups. From a clinical perspective the findings are clear that STS without the use of arms or having arms fixed to the chest is able to detect differences between fallers and non-fallers, however it is not clear (as it was not investigated) whether performance of STS using arms differs between fallers and non-fallers.

Instructions to the participants on how quickly to complete the tasks varied between studies. Three studies ${ }^{14,15,21}$ asked participants to move as fast as possible, while others ${ }^{16,18,19}$ allowed for a self-selected speed. Asking an individual to complete tasks as fast as possible requires them to utilize the absolute capacity of their function. Moving rapidly challenges the ability to generate rapid muscle activity ${ }^{30}$ however it also challenges the balance system, requiring faster feedback and feedforward to iteratively control the movement of the centre of mass. Moreover rapid motion may also challenge fear of falling, where an individual is not willing to 'push' the movement through fear of the consequences. It may be for these reasons that those studies employing a 'fast as possible' instruction demonstrate significant differences in time to complete STS between fallers and non-fallers. ${ }^{14,15}$ In contrast, the study employing a self-selected speed failed to demonstrate a difference. ${ }^{16}$ It is therefore possible that the habitual movement strategies employed by both groups are similar in terms of STS speed with differences only becoming evident when additionally challenged.

During standing the width of a person's stance determines the base of support and has an inherent influence on standing balance. Therefore the manipulation of the base of support from wide stance to narrow stance is likely to challenge the postural control mechanisms to a greater extent. ${ }^{31}$ There were a wide variety of foot positions 
used when studying postural control, ranging from narrow stance (feet touching), to wide stance. Interestingly, of the four articles studying the CoPv, two found a significant difference between fallers and non-fallers ${ }^{23,25}$ and this was determined when participants were in narrow and near narrow ( $2 \mathrm{~cm}$ heel separation) stance. In contrast, those studies that did not find a difference ${ }^{25,26}$ assessed participants in a wider stance. This finding was consistent for CoP path length where difference were found with narrow ${ }^{23,25}$ but not wide stance. ${ }^{25}$ Therefore this suggests intrinsic differences are evident between fallers and non-fallers in postural sway, however only when employing a narrow or near narrow stance. However this was only the case for the variables of CoP path length and $\mathrm{CoPv}$. The direction specific breakdown of CoP path length and sway did not demonstrate any additional information. AP CoP path length was found consistently not to be different between fallers and non-fallers. ${ }^{23,27}$ Conflicting findings were evident for the ML CoP path length, ${ }^{23,27}$ however it was unclear how the outcome metrics were calculated in Park et al. ${ }^{27}$ making the direct comparison difficult. The variables of CoP sway distance in the AP and ML directions where observed in four studies, no direction specific differences were found ${ }^{23,25-27}$ with only one detecting a difference. ${ }^{23}$ These results overall question the relevance of directional breakdown suggesting this additional detail may not be beneficial in identifying fallers from non-fallers.

Therefore the findings of this review suggest that the outcomes of CoP path length and velocity during postural sway be used if trying to identify differences between fallers and non-fallers during a near narrow or narrow stance.

The position of a person's arms whilst standing has also been shown to have an effect on standing balance by shifting the centre of mass and centre of gravity. Despite this, two articles do not fully describe the protocol regarding arm position. 
${ }^{18,22}$ Four articles kept arms by the side ${ }^{23,24,26,27}$ and one positioned them behind their back. ${ }^{25}$ Fixing a person's arm position (such as behind their back) will have altered the available equilibrium and righting reactions available to control for postural sway. It could be argued that this would challenge the individual more. However arm position seemed not to be affect the ability to detect differences between fallers and non-fallers during postural sway.

\section{Limitations}

This study was limited by investigating healthy elderly people, removing articles pertaining to individuals with co-morbidities that could be considered to be associated with their falls. As it is commonplace for elderly individuals to have various comorbidities, the extrapolation of our findings to these populations should be done with caution. There was also significant heterogeneity between the reviewed studies with regards to the techniques used to assess the different tasks and the level of descriptions of these tasks. Although in some cases this allowed extra conclusions to be drawn it has generally limited the depth to which the data could be synthesized. Only English language articles were included, which could result in publication bias and limit the generalizability of the results, however, the articles included in this study were from a wide variety of countries and cultures.

\section{Conclusion}

The findings of this review suggest that fallers differ from non-fallers with respect to how they complete activities of daily living. Fallers stood from sitting significantly 
slower, with lower linear velocity and maximum power than non-fallers. This was best observed when arms were not used and when the stand was attempted as quickly as possible. Fallers displayed significantly greater sway path lengths and centre of pressure velocity compared with non-fallers, but only when assessed in narrow or near narrow stance. Fallers used less force during stepping up compared with nonfallers. This demonstrates that activities of daily living can be used to identify impairments evident in fallers and therefore offer the potential for community based assessment of fallers. 


\section{References}

1. World Health Organization (WHO). Injuries and violence: the facts. Geneva, WHO Press; 2010.

2. Tian Y, Thompson J, Buck D, et al. Exploring the system-wide costs of falls in older people in Torbay. London: The King's Fund; 2013.

3. WHO. WHO global report on falls prevention in older age. Geneva: WHO Press; 2007.

4. National Institute for Health and Care Excellence (NICE). Falls in older people: assessing risk and prevention. London: NICE; 2013. NICE guideline CG161.

5. Todd C, Skelton D. What are the main risk factors for falls amongst older people and what are the most effective interventions to prevent these falls. Copenhagen: WHO Regional Office for Europe; 2004.

6. Office for National Statistics. Overview of the UK population: July 2017. Newport: Office for National Statistics; 2017.

7. Duncan PW, Studenski S, Chandler J, et al. Functional reach: predictive validity in a sample of elderly male veterans. J. Gerontol Med Sci. 1992;47(3):M93- M98.

8. Shumway-Cook A, Brauer S, Woollacott M. Predicting the probability for falls in community-dwelling older adults using the timed up \& go test. Phys Ther. 2000;80(9):896-903.

9. Drover D, Howcroft J, Kofman J, et al. Faller classification in older adults using wearable sensors based on turn and straight-walking accelerometer-based features. Sensors. 2017;17(6):e1321.

10. Lee RY, Carlisle AJ. Detection of falls using accelerometers and mobile phone technology. Age Ageing. 2011;40(6):690-6.

11. Kowal P, Dowd JE. Definition of an older person: Proposed working definition of an older person in Africa for the MDS Project. Geneva: WHO; 2001.

12. Quality assessment tool for observational cohort and cross-sectional studies [Internet]. Maryland: National Heart, Lung and Blood Institute; 2014. 
Available from: https://www.nhlbi.nih.gov/health-pro/guidelines/indevelop/cardiovascular-risk-reduction/tools/cohort

13. Wardle J, Steel A. Systematic reviews in integrative medicine: a clinician's guide to publications. Advances in Integrative Medicine. 2015;2(2):103-9.

14. Cheng Y, Wei S, Chen P, et al. Can sit-to-stand lower limb muscle power predict fall status? Gait Posture. 2014;40(3):403-7.

15. Ejupi A, Brodie M, Gschwind YJ, et al. Kinect-based five-time-sit-to-stand test for clinical and in-home assessment of fall risk in older people. Gerontology. 2016;62(1):118-124.

16. Ejupi A, Brodie M, Lord SR, et al. Wavelet-based sit-to-stand detection and assessment of fall risk in older people using a wearable pendant device. IEEE Trans Biomed Eng. 2017;64(7):1602-7.

17. Iluz T, Weiss A, Gazit E, et al. Can a body-fixed sensor reduce Heisenberg's uncertainty when it comes to the evaluation of mobility? Effects of aging and fall risk on transitions in daily living. J. Gerontol Med Sci. 2016;71(11):145965.

18. Lázaro M, González A, Latorre G, et al. Postural stability in the elderly: fallers versus non-fallers. Eur Geriatr Med [online], 2011;2(1):1-5.

19. Liang S, Ning Y, Li H, et al. Feature selection and predictors of falls with foot force sensors using KNN-based algorithms. Sensors. 2015;15(11):29393-407.

20. Panzer VP, Wakefield DB, Hall CB, et al. Mobility assessment: sensitivity and specificity of measurement sets in older adults. Arch Phys Med Rehabil. 2011;92(6):905-12.

21. Yamada T, Demura S, Takahashi K. Centre of gravity transfer velocity during sit-to-stand is closely related to physical functions regarding fall experience of the elderly living in community dwelling. Health. 2013;5(12):2097-103.

22. Aoki M, Nishihori T, Jiang $Y$, et al. Damping control of balance in the medial/lateral direction and the risk of falling in the elderly. Geriatr Gerontol Int. 2013;13(1):182-9.

23. Bauer CM, Gröger I, Rupprecht R, et al. Prediction of future falls in a community dwelling older adult population using instrumented balance and gait analysis. Z Gerontol Geriatr. 2016;49(3):232-6. 
24. Berger L, Chuzel M, Buisson G, et al. Undisturbed upright stance control in the elderly: part 2. Postural-control impairments of elderly fallers. J Mot Behav. 2005;37(5):359-66.

25. Melzer I, Benjuya N, Kaplanski J. Postural stability in the elderly: a comparison between fallers and non-fallers. Age Ageing. 2004;33(6):602-7.

26. Merlo A, Zemp D, Zanda E, et al. Postural stability and history of falls in cognitively able older adults: the Canton Ticino study. Gait Posture. 2012;36(4):662-6.

27. Park JW, Jung M, Kweon M. The mediolateral CoP parameters can differentiate the fallers among the community-dwelling elderly population. J Phys Ther Sci. 2014;26(3):381-4.

28. Williams JM, Haq I, Lee RY. Is pain the cause of altered biomechanical functions in back pain sufferers? Hum Mov Sci. 2010;29(2):311-25.

29. Novy D, Simmonds M, Lee C. Physical performance tasks: what are the underlying constructs? Arch Phys Med Rehabil. 2002;83(1):44-7.

30. Lindermann $\mathrm{U}$, Claus $\mathrm{H}$, Stuber $\mathrm{M}$, et al. Measuring power during the sit-tostand transfer. Eur J Appl Physiol. 2003;89(5):466-70.

31. Bonnet CT, Mercier M, Szaffarczyk S. Impaired mediolateral postural control at the ankle in healthy, middle-aged adults. J Mot Behav. 2013;45(4):333-42. 
Figure Captions

Figure 1. PRISMA diagram for sit-to-stand search.

Figure 2. PRISMA diagram for stairs search.

Figure 3. PRISMA digram for postural sway search. 

Table 1 - Search terms for sit-to-stand, stairs and postural sway

\begin{tabular}{|c|c|}
\hline Boolean Function & Search terms \\
\hline \multicolumn{2}{|l|}{ Sit to stand } \\
\hline & Fall* \\
\hline AND & $\begin{array}{l}\text { Elderly OR aged OR older OR elder OR geriatric OR elderly } \\
\text { people OR old people OR senior }\end{array}$ \\
\hline AND & Sit-to-stand OR transfer* OR STS \\
\hline AND & $\begin{array}{l}\text { Kinematics OR biomechanics OR mechanics OR velocity OR } \\
\text { kinetics }\end{array}$ \\
\hline \multicolumn{2}{|l|}{ Stairs } \\
\hline & Fall* \\
\hline AND & $\begin{array}{l}\text { Elderly OR aged OR older OR elder OR geriatric OR elderly } \\
\text { people OR old people OR senior }\end{array}$ \\
\hline AND & Stair* OR step* \\
\hline AND & $\begin{array}{l}\text { Kinematics OR biomechanics OR mechanics OR velocity OR } \\
\text { kinetics }\end{array}$ \\
\hline AND & $\begin{array}{l}\text { Ascending OR descending OR going up OR going down OR } \\
\text { walking up OR walking down OR using OR use }\end{array}$ \\
\hline \multicolumn{2}{|l|}{ Postural Sway } \\
\hline & Fall* (searched for within title) \\
\hline AND & $\begin{array}{l}\text { Elderly OR aged OR older OR elder OR geriatric OR elderly } \\
\text { people OR old people OR senior }\end{array}$ \\
\hline AND & Balance OR sway OR stability OR postural control \\
\hline AND & Standing OR static \\
\hline NOT & Training OR treatment OR intervention OR rehabilitation \\
\hline
\end{tabular}


Table 2 - Data extraction table for STS

\begin{tabular}{|c|c|c|c|c|}
\hline $\begin{array}{l}\text { Author \& } \\
\text { Date }\end{array}$ & $\begin{array}{l}\text { Participants \& faller } \\
\text { definition }\end{array}$ & Task and Equipment Used & Measurement and Algorithms Employed & Findings \\
\hline Cheng et al. ${ }^{14}$ & $\begin{array}{l}\text { - } \quad 70 \text { elderly participants } \\
\text { - } \quad 35 \text { Non-fallers } \\
\text { - } \quad 35 \text { Fallers } \\
\text { Place of recruitment not } \\
\text { specified } \\
\text { - } \quad \text { Fallers: } \\
\text { O Age } 77.5 \pm 7.79 \text { years } \\
\text { O Gender } 63 \% \text { male } \\
\quad \text { Body weight (BW) } \\
\quad 60.58 \pm 12.89 \mathrm{~kg} \\
\text { - Non-Fallers: } \\
\quad \text { Age } 75.23 \pm 6.43 \\
\quad \text { years } \\
\quad 67 \% \text { male } \\
\text { B } \quad \text { Faller definition: Self- } \\
\text { reported history of } \\
\text { falling within the last } 12 \\
\text { months } \\
\text { Fall definition: } \\
\text { unintentional coming to } \\
\text { a lower level not caused } \\
\text { by any external force or } \\
\text { influence }\end{array}$ & 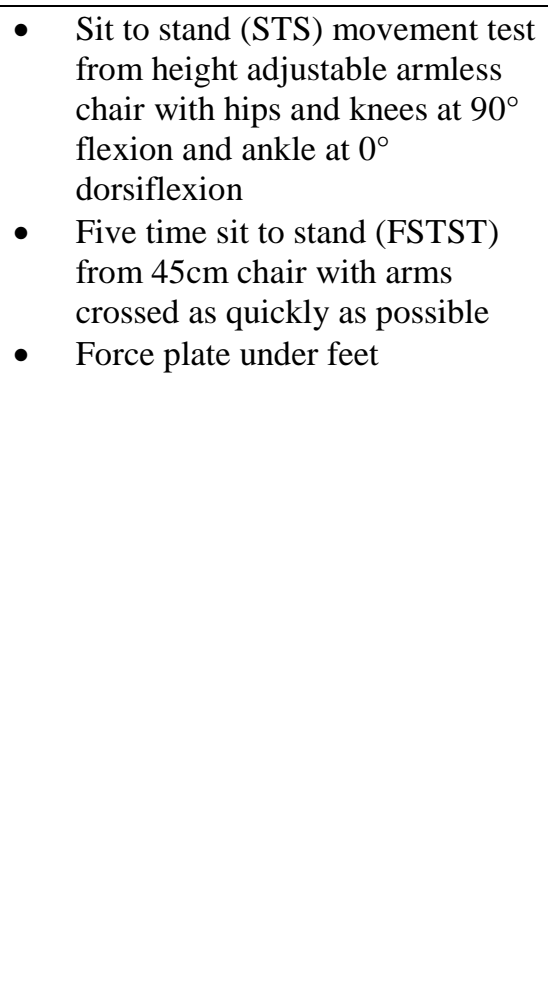 & $\begin{array}{l}\text { - Maximum vertical ground reaction force } \\
\text { (MVGRF) (N/BW)\% } \\
\text { Max force generated normalized to body } \\
\text { weight (BW) } \\
\text { - Maximum power (MP) (W/kg) } \\
\text { Max product VGRF and vertical velocity } \\
\text { of centre of mass normalized to BW } \\
\text { - Peak-to-trough VGRF difference per unit } \\
\text { time (PtT/s) (N/s) } \\
\text { Difference between max and min VGRF } \\
\text { by time } \\
\text { Preparation phase (PP) (s) } \\
\text { Began with change of } 2.5 \% \text { in vertical } \\
\text { force and ended when MVGRF reached } \\
\text { Rising phase (RP) (s) } \\
\text { Began at MVGRF and ended when the } \\
\text { VGRF equaled the subject's BW } \\
\text { Stabilization phase (SP) (s) } \\
\text { Began when VGRF equaled subject's BW } \\
\text { and ended when VGRF oscillated with } \\
2.5 \% \text { of subject's BW }\end{array}$ & $\begin{array}{l}\text { - Significant difference: } \\
\quad \text { MP significantly greater in non- } \\
\text { fallers than fallers } \\
\circ \quad \text { PP, RP and SP each significantly } \\
\text { longer in F group than NF group } \\
\text { - No significant difference: } \\
\quad \text { MVGRF } \\
\text { - Total times for STS between fallers } \\
\text { and non-fallers not compared post hoc }\end{array}$ \\
\hline Ejupi et al. ${ }^{15}$ & $\begin{array}{l}\text { - } 94 \text { community dwelling } \\
\text { elderly participants } \\
\text { from a retirement } \\
\text { village in Sydney, }\end{array}$ & $\begin{array}{l}\text { 5TSTS as quickly as possible } \\
\text { from a } 45 \mathrm{~cm} \text { chair with arms } \\
\text { crossed }\end{array}$ & $\begin{array}{ll}\text { - } & \text { Total time to complete }(\mathrm{s}) \\
\text { - } & \text { Mean sit-to-stand velocity (vertical) }(\mathrm{m} / \mathrm{s}) \\
\text { - } & \text { Mean sitting time }(\mathrm{s})\end{array}$ & $\begin{array}{l}\text { - Significant difference: } \\
\quad \text { Fallers slower than non-fallers for } \\
\text { total time as measured by kinect } \\
\text { and stopwatch }\end{array}$ \\
\hline
\end{tabular}




\begin{tabular}{|c|c|c|c|c|}
\hline $\begin{array}{l}\text { Author \& } \\
\text { Date }\end{array}$ & $\begin{array}{l}\text { Participants \& faller } \\
\text { definition }\end{array}$ & Task and Equipment Used & Measurement and Algorithms Employed & Findings \\
\hline & $\begin{array}{ll} & \text { Australia } \\
\text { - } & 66(70 \%) \text { Female/28 } \\
& (30 \%) \text { Male } \\
\text { - } & 29 \text { Fallers } \\
\text { - } & 65 \text { Non-fallers } \\
\text { - } & \text { Fallers: } \\
& \text { Age } 80.6 \pm 6.7 \text { years } \\
\circ \quad \text { BW } 67.2 \pm 10.8 \mathrm{~kg} \\
\text { - } \quad \text { Non-fallers: } \\
\circ \quad \text { Age } 79.3 \pm 6.3 \text { years } \\
\circ \quad \text { BW 71.6 } 13.7 \mathrm{~kg} \\
\text { - } \quad \text { Faller definition: One or } \\
\text { more fall in the previous } \\
12 \text { months }\end{array}$ & $\begin{array}{l}\text { - Measured using kinect motion } \\
\text { camera and stopwatch }\end{array}$ & $\begin{array}{ll}\text { - } & \text { Mean standing time }(\mathrm{s}) \\
\text { - } & \text { Mean stand-to-sit velocity }(\mathrm{m} / \mathrm{s})\end{array}$ & $\begin{array}{l}\circ \text { Fallers had lower mean vertical } \\
\text { velocity than non-fallers } \\
\text { - No significant difference: } \\
\circ \text { Mean sitting time } \\
\circ \text { Mean standing time } \\
\circ \text { Mean stand to sit velocity }\end{array}$ \\
\hline Ejupi et al. ${ }^{16}$ & $\begin{array}{l}\text { - } 94 \text { community dwelling } \\
\text { elderly participants } \\
\text { living in Sydney, } \\
\text { Australia. } \\
\text { - } 64 \text { female/30 male } \\
\text { - } \\
\text { Age } 79.9 \pm 6.5 \text { years } \\
\text { Faller definition: Self- } \\
\text { reported fall within the } \\
\text { last year } \\
\text { - Fall definition: an } \\
\text { unexpected event in } \\
\text { which the person comes } \\
\text { to rest on the ground, } \\
\text { floor or lower level }\end{array}$ & $\begin{array}{l}\text { - Stand from a } 45 \mathrm{~cm} \text { chair, walk } \\
10 \mathrm{~m} \text { and sit down on a second } \\
\text { chair at a comfortable speed } \\
\text { Pendent worn around neck under } \\
\text { cloths consisting of a triaxial } \\
\text { accelerometer and a barometetric } \\
\text { air pressure sensor }\end{array}$ & $\begin{array}{ll}\text { - } & \text { STS: } \\
\circ & \text { Duration }(\mathrm{s}) \\
\circ & \text { Max resultant acceleration of the sensor } \\
& \left(\mathrm{m} / \mathrm{s}^{2}\right) \\
\circ & \text { Max velocity of the sensor }(\mathrm{m} / \mathrm{s}) \\
\circ & \text { Peak power }(\mathrm{W})(\text { assumption main } \\
& \text { components of force and velocity were } \\
& \text { vertical) } \\
\circ \quad \text { Max forward lean }\left({ }^{\circ}\right) \\
\circ \quad \text { Direction of max acceleration or velocity } \\
\text { not specified } \\
\text { - Acceleration signal's vector magnitude } \\
\text { calculated } \\
\text { - Integration of acceleration to get velocity } \\
\text { - Power calculated by multiplying force }(\mathrm{F}=\mathrm{ma}\end{array}$ & 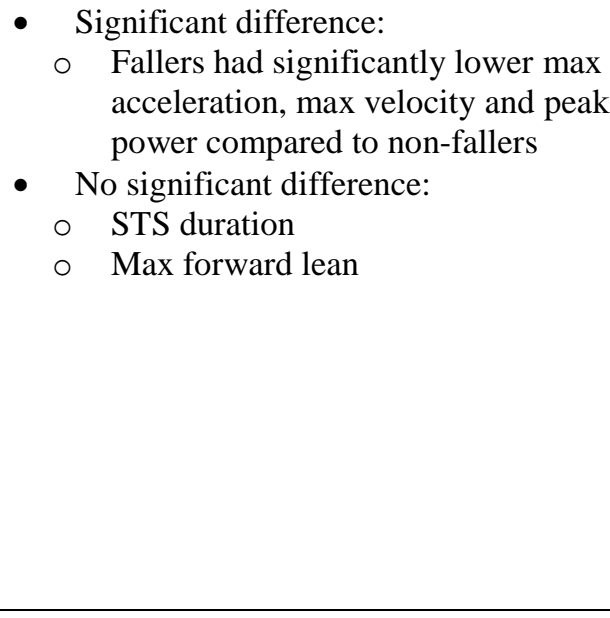 \\
\hline
\end{tabular}




\begin{tabular}{|c|c|c|c|c|}
\hline $\begin{array}{l}\text { Author \& } \\
\text { Date }\end{array}$ & $\begin{array}{l}\text { Participants \& faller } \\
\text { definition }\end{array}$ & Task and Equipment Used & Measurement and Algorithms Employed & Findings \\
\hline & & & $\begin{array}{l}\text { where mass is of the whole body) by velocity } \\
\text { Duration estimated by the maximum of the } \\
\text { absolute value of the wavelet coefficients }\end{array}$ & \\
\hline Lázaro et al. ${ }^{18}$ & $\begin{array}{ll} & 226 \text { participants } \\
\text { community dwelling } \\
\text { elderly participants } \\
\text { living in Madrid, Spain } \\
\text { - } & 113 \text { recurrent fallers } \\
\text { - } & 113 \text { controls } \\
85 \% \text { women and mean } \\
\text { age of } 78 \pm 5 \text { years } \\
\text { - } & \text { Faller definition: Had } \\
\text { undergone two or more } \\
\text { falls in the previous } 6 \\
\text { months and had visited } \\
\text { their GP or Geriatrician } \\
\text { (self reported) }\end{array}$ & $\begin{array}{ll} & \text { STS without any push off } \\
\text { - } & \text { Exact method for test not well } \\
\text { explained } \\
\text { - } & \text { Performed on a Balance } \\
& \text { Master }{ }^{\circledR} \text { force platform }\end{array}$ & - $\quad$ STS median time (s) & $\begin{array}{ll}\text { - } & \text { Fallers were significantly slower in } \\
\text { STS compared to non-fallers }\end{array}$ \\
\hline Liang et al. ${ }^{19}$ & $\begin{array}{ll}\text { - } & 38 \text { community dwelling } \\
& \text { elderly participants } \\
\text { - } & 23 \text { Fallers } \\
\text { - } & 15 \text { Non-fallers } \\
\text { - } \quad \text { Fallers: } \\
\quad \quad \text { Age } 72.29 \pm 4.98 \text { years }\end{array}$ & $\begin{array}{ll} & \text { STS from an armless chair } \\
\text { - } & \text { Performed stood on MatScan }{ }^{\circledR} \\
\text { system }\end{array}$ & $\begin{array}{l}\text { - Ground reaction force (GRF) of each foot } \\
\text { during STS } \\
\text { - GRF normalized to patients body weigh and } \\
\text { then sample entropy was calculated for each } \\
\text { feature using } \mathrm{m}=2 \text { and } \mathrm{r}=0.25 \\
\text { - This was done using K-nearest neighbor rule }\end{array}$ & $\begin{array}{l}\text { Fallers has significantly lower left and } \\
\text { right foot vertical ground reaction } \\
\text { forces in STS compared to non-fallers } \\
\text { - }\end{array}$ \\
\hline
\end{tabular}




\begin{tabular}{|c|c|c|c|c|}
\hline $\begin{array}{l}\text { Author \& } \\
\text { Date }\end{array}$ & $\begin{array}{l}\text { Participants \& faller } \\
\text { definition }\end{array}$ & Task and Equipment Used & Measurement and Algorithms Employed & Findings \\
\hline & $\begin{array}{ll} & 42.85 \% \text { male } \\
\circ & \text { BW } 65.92 \pm 10.17 \mathrm{~kg} \\
-\quad & \text { Non-fallers } \\
\circ & \text { Age } 69.93 \pm 4.51 \text { years } \\
\circ & 45.83 \% \text { male } \\
\circ & \text { BW } 58.33 \pm 18.18 \mathrm{~kg} \\
\text { - } & \text { Faller definition: Self } \\
\text { reported fall within the } \\
\text { last year } \\
\circ \quad \text { Not including falls } \\
\quad \text { from unavoidable } \\
\text { environmental } \\
\text { hazards such as a } \\
\text { chair collapsing or } \\
\text { walking on ice }\end{array}$ & & & \\
\hline Panzer et al. ${ }^{20}$ & $\begin{array}{l}74 \text { community dwelling } \\
\text { elderly participants } \\
\text { - } 27 \mathrm{NF} \text { : age } 75.1 \pm 6.5, \\
\text { - } 47 \mathrm{~F} \text { age } 80.1 \pm 6.2 \\
\text { No difference between } \\
\text { groups by sex } \\
\text { - Faller definition: Two } \\
\text { or more non-injury falls } \\
\text { within the last year or } \\
\text { one or more injurious } \\
\text { falls }\end{array}$ & $\begin{array}{l}\text { - } \quad \text { STS from a } 41.4 \mathrm{~cm} \text { height chair } \\
\text { with arms crossed } \\
\text { - }\end{array}$ & $\begin{array}{l}\text { STS - Time (s), sway area and mediolateral } \\
\text { (ML) and anteroposterior (AP) excursion } \\
\text { Time was measured from the onset of AP } \\
\text { force until the vertical force reached BW. } \\
\text { - Sway area was calculated from this point } \\
\text { until variance was less than 1SD for more } \\
\text { than } 5 \text { seconds. } \\
\text { ML and AP excursion values were } \\
\text { determined from anterior-posterior and } \\
\text { vertical phases }\end{array}$ & $\begin{array}{ll}- & \text { Fallers had significantly larger STS } \\
\text { sway areas and STS ML excursion } \\
\text { - } & \text { Tasks with ICC }<0.6 \text { and P }>0.01 \text { were } \\
\text { excluded from further evaluation }\end{array}$ \\
\hline Yamada et & $\begin{array}{l}45 \text { community dwelling } \\
\text { elderly participants split } \\
\text { into three groups of } 15\end{array}$ & $\begin{array}{l}\text { STS while bare foot with feet } \\
\text { shoulder width apart, } 90^{\circ} \text { ankle } \\
\text { angle, crossed arms and as }\end{array}$ & $\begin{array}{l}\text { Centre of gravity }(\mathrm{CoG}) \text { transfer velocity } \\
\text { from abdomen to spine as represented by } \\
\text { crista iliaca transfer velocity measure by the }\end{array}$ & $\begin{array}{l}\text { Non-fallers had significantly greater } \\
\text { CoG maximum and mean transfer } \\
\text { velocities compared to both faller }\end{array}$ \\
\hline
\end{tabular}




\begin{tabular}{|c|c|c|c|c|}
\hline $\begin{array}{l}\text { Author \& } \\
\text { Date }\end{array}$ & $\begin{array}{l}\text { Participants \& faller } \\
\text { definition }\end{array}$ & Task and Equipment Used & Measurement and Algorithms Employed & Findings \\
\hline al. $^{21}$ & $\begin{array}{l}\text { non-fallers, fallen once } \\
\text { per year and fallen more } \\
\text { than two times per year } \\
\text { - } \quad \text { Non-fallers: } \\
\circ \quad \text { Age } 75.7 \pm 4.8 \text { year } \\
\circ \quad \text { BW } 53.0 \pm 6.4 \mathrm{~kg} \\
\text { - Single fallers: } \\
\quad \text { Age } 75.7 \pm 5.0 \text { years } \\
\circ \quad \text { BW } 51.6 \pm 8.4 \mathrm{~kg} \\
\text { - Two or more falls per } \\
\text { year } \\
\circ \quad \text { Age } 75.7 \pm 4.8 \text { years } \\
\circ \quad \text { BW } 55.9 \pm 6.3 \mathrm{~kg} \\
\text { - No gender info given } \\
\text { - Definition of past falls } \\
\text { and fall not stated } \\
\end{array}$ & $\begin{array}{l}\text { quickly as possible from a chair } \\
\text { adjusted to knee height of each } \\
\text { patient } \\
\text { Performed while participant } \\
\text { connected to FITRO Dyne } \\
\text { Premium - measures length of a } \\
\text { pulled or returned cord from the } \\
\text { bobbin, which works with a built } \\
\text { in rotatory encoder. Subject } \\
\text { wears belt around their waist to } \\
\text { which the cord is attached to the } \\
\text { left Crista iliaca position of the } \\
\text { belt }\end{array}$ & $\begin{array}{l}\text { time change of the pulled or returned cord } \\
\text { length. } \\
\text { - Highest value and mean values used. }(\mathrm{cm} / \mathrm{s}) \\
\text { - ANOVA used for analysis between groups } \\
\text { Tukey's honestly significant difference test } \\
\text { used post-hoc }\end{array}$ & $\begin{array}{l}\text { groups and the single fall group had } \\
\text { significantly greater CoG maximum } \\
\text { and mean transfer velocities compared } \\
\text { to the multiple falls group } \\
\text { - Exact orientation of CoG movement } \\
\text { velocity not stated }\end{array}$ \\
\hline Iluz et al. ${ }^{17}$ & $\begin{array}{l}\text { - } 71 \text { elderly participants } \\
\text { - } 38 \text { healthy older adults } \\
33 \text { idiopathic elderly } \\
\text { fallers } \\
\text { - } \quad \text { Fallers } \\
\quad \quad \text { Age } 77.89 \pm 4.99 \\
\quad \text { years } \\
\quad 66.66 \% \text { women } \\
\text { - Non-fallers } \\
\circ \quad \text { Age } 78.65 \pm 4.35 \\
\circ \quad 63.15 \% \text { women } \\
\text { - No significant } \\
\text { differences between } \\
\text { fallers and non-fallers in } \\
\text { baseline characteristics }\end{array}$ & $\begin{array}{l}\text { - Participants wore a small } \\
\text { lightweight sensor on a belt on } \\
\text { their lower back that consisted of } \\
\text { a tri-axial accelerometer and } \\
\text { gyroscope. } \\
\text { Sensor worn for } 3 \text { consecutive } \\
\text { days while performing normal } \\
\text { activities at home } \\
\text { - Lying, standing, sitting and } \\
\text { walking parts of signal identified } \\
\text { Accelerometer collected } \\
\text { acceleration signals in vertical, } \\
\text { ML and AP directions and } \\
\text { gyroscope provided yaw, pitch } \\
\text { and roll }\end{array}$ & $\begin{array}{l}\text { - Sit to walk and walk to sit analyzed within } \\
\text { data } \\
\text { Temporal and distribution data collected, } \\
\text { only temporal reported here } \\
\text { Duration (msec), range (g), jerk (g/msec) and } \\
\text { standard deviation of acceleration signal (SD) } \\
\text { (g) were collected for each of the vertical, AP } \\
\text { and pitch components of the temporal and } \\
\text { distribution data sets for both sit to walk and } \\
\text { walk to sit. } \\
\text { Required pitch angular velocity to be above } \\
\text { 15deg/sec in any transition } \\
\text { Required the absolute value of change in the } \\
\text { AP range between the mean of the first half } \\
\text { and the mean of the second half transition }\end{array}$ & $\begin{array}{l}\text { - Significant difference } \\
\circ \quad \text { Fallers had lower vertical STD of } \\
\text { temporal walk to sit } \\
\circ \quad \text { Fallers had lower AP STD of } \\
\text { temporal walk to sit } \\
\text { - All other differences in variable were } \\
\text { found to no be significant }\end{array}$ \\
\hline
\end{tabular}




\begin{tabular}{|l|l|l|l|l|}
\hline Author \& & Participants \& faller & Task and Equipment Used & Measurement and Algorithms Employed & Findings \\
\hline & definition & $\begin{array}{l}\text { Faller definition: At } \\
\text { least 2 falls in the } \\
\text { previous year }\end{array}$ & & $\begin{array}{l}\text { window (window defined as 10s) was above } \\
0.3 \mathrm{~g} \text { and that the range of the sitting part } \\
\text { must be below 0.4g to confirm sitting } \\
\text { Start and end of each transition identified by } \\
\text { identifying max and min points in the signals } \\
\text { Each axis expressed different aspects or } \\
\text { components of the movement } \\
\text { Post hoc analysis between fallers and older } \\
\text { non-fallers }\end{array}$ \\
\hline
\end{tabular}

Note. BW, Body Weight; STS, sit-to-stand; kg, kilogrammes; FSTST, five time sit to stand test; MVGRF, maximum ground reaction force; N, Newtons; MP, maximum

power; VGRF, vertical ground reaction force; PP, preparation phase; RP, rising phase; SP, stabilization phase; $\mathrm{s}$, seconds; m/s, metres per second; $\mathrm{cm}$, centimetres; m, metres;

W, Watts peak power; $\mathrm{m} / \mathrm{s}^{2}$, metres per second per second. GRF, ground reaction force; Anteroposterior, AP; ICC, intraclass correlation coefficient; SD, standard deviation;

CoG, centre of gravity; msec, milliseconds; g, gravity; ML, mediolateral. 
Table 3 - Data extraction table for postural sway

\begin{tabular}{|c|c|c|c|c|}
\hline $\begin{array}{l}\text { Author \& } \\
\text { Date }\end{array}$ & Participants & Task and Equipment Used & Measurement and algorithms employed & Findings \\
\hline Aoki et al. ${ }^{22}$ & $\begin{array}{l}\text { - } 23 \text { elderly participants } \\
\text { who visited Gifu } \\
\text { University Hospital, } \\
\text { Japan } \\
\text { - } \quad 9 \text { male/14 female } \\
\text { - } \quad 4 \text { fallers } \\
\text { - } \quad 19 \text { non-fallers } \\
\text { - } \quad \text { No significant } \\
\text { difference between } \\
\text { average age of groups } \\
\text { - } \quad \text { Fallers: } \\
\quad \text { Age } 79.5 \pm 2.4 \\
\text { - } \quad \text { years } \\
\text { Non-fallers: } \\
\text { Age } 74.2 \pm 6.8 \\
\text { years } \\
\text { Self reported fall in } \\
\text { the past year }\end{array}$ & $\begin{array}{l}\text { Participants asked to maintain } \\
\text { standing with a } 30 \text {-degree angle } \\
\text { between the medial sides of their } \\
\text { feet and a heel-to-heel separation } \\
\text { of approx. } 2 \mathrm{~cm} \text {. } \\
\text { Told to look ahead at a } 2 \mathrm{~cm} \\
\text { marker at eye level at a distance of } \\
1.5 \mathrm{~m} \text { away. } \\
\text { Participants wore a white vest with } \\
\text { a } 3 \mathrm{~cm} \text { diameter black circular } \\
\text { marker attached on the back of the } \\
\text { vest at the level of the fourth } \\
\text { thoracic vertebrae. } \\
\text { The marker on back was tracked } \\
\text { by complementary metal oxide } \\
\text { semiconductor camera } \\
\text { (ARTCAM-130MI) located } 1.5 \mathrm{~m} \\
\text { behind participants back } \\
60 \text { seconds worth of tracking was } \\
\text { recorded with a capture resolution } \\
\text { set to } 640 \text { (x direction) X } 480 \\
\text { pixels and recording } 15 \text { frames per } \\
\text { second }\end{array}$ & $\begin{array}{l}\text { - } \\
\text { - } \\
\text { - } \mathrm{K}_{\mathrm{P}} / \mathrm{K}_{\mathrm{D}} \text { ratio (Stiffness/Damping ratio) } \\
\text { The image of the marker was binarized with a } \\
\text { differentiating histogram method and the } \\
\text { locus of the center of the image was } \\
\text { recognized and recorded on the computer } \\
\text { system } \\
\text { The scalar of the locus on real coordinates } \\
\text { could be calculated by the number of pixels } \\
\text { equivalent to the diameter of the marker }\end{array}$ & $\begin{array}{l}\text { - Significant difference } \\
\quad \text { Fallers had significantly higher } \\
\quad \mathrm{K}_{\mathrm{P}} / \mathrm{K}_{\mathrm{D}} \text { ratios } \\
\text { - No significant difference: } \\
\quad \text { TSSX }(\mathrm{mm} / \mathrm{s})\end{array}$ \\
\hline Bauer et al. ${ }^{23}$ & $\begin{array}{l}\text { - } 75 \text { community } \\
\text { dwelling older adults } \\
\text { - } 22 \text { men/62 female } \\
\text { - } \quad 49 \text { Non-Fallers } \\
\quad \text { Age } 78.9 \pm 5.8\end{array}$ & $\begin{array}{l}\text { All trials were conducted by same } \\
\text { two researchers } \\
\text { - Participants stood quietly for } 30 \mathrm{~s} \\
\text { - } \quad \text { Data was recorded for the last } \\
25.6 \mathrm{~s}\end{array}$ & $\begin{array}{ll}\text { - } & \text { Mean speed of centre of pressure (CoP) in } \\
\mathrm{mm} / \mathrm{s}\end{array}$ & $\begin{array}{l}\text { Significant difference: } \\
\text { Fallers had greater mean velocity in } \\
\text { 2cm heel separation stance and } \\
\text { narrow stance compared to non- } \\
\text { fallers }\end{array}$ \\
\hline
\end{tabular}




\begin{tabular}{|c|c|c|c|c|}
\hline $\begin{array}{l}\text { Author \& } \\
\text { Date }\end{array}$ & Participants & Task and Equipment Used & Measurement and algorithms employed & Findings \\
\hline & $\begin{array}{ll}\text { - } & \text { 28 Fallers } \\
& \quad \text { Age } 79.4 \pm 6.9 \\
\text { - } & \text { Not significant } \\
& \text { difference in age } \\
\text { between fallers and } \\
\text { non-fallers } \\
\text { - } \\
\text { Faller definition: Self } \\
\text { reported falls the in } \\
\text { past year } \\
\text { Fall definition: } \\
\text { According to the } \\
\text { criteria of the } \\
\text { prevention of falls } \\
\text { network Europe group }\end{array}$ & $\begin{array}{l}\text { - Shoes removed throughout } \\
\text { Told to look straight ahead at a } \\
\text { point } 90 \mathrm{~cm} \text { in front of them with } \\
\text { their head up and their arms } \\
\text { resting by their sides } \\
\text { - Instructed to maintain balance } \\
\text { - Heel distance } 2 \mathrm{~cm} \text { and } 30^{\circ} \text { angle } \\
\text { between their feet } \\
\text { - Then narrow stance (ankles and } \\
\text { toes touching) } \\
\text { - Performed on a SATEL force plate }\end{array}$ & $\begin{array}{ll} & \text { and AP) } \\
\text { Amplitude of the CoP movement in ML and } \\
\text { AP directions } \\
\text { Quotient of both directions } \\
\text { (AmpML/AmpAP) } \\
\text { - Coefficient of sway direction } \\
\text { - The frequency of the signal by means of fast } \\
\text { Fourier transformations for the ML and AP } \\
\text { signals } \\
\text { - Frequency content was divided into three } \\
\text { categories }(0-0.5 \mathrm{Hx}, 0.5-2 \mathrm{~Hz},<2 \mathrm{~Hz} \text { ) and the } \\
\text { energy content for each sway frequency was } \\
\text { reported } \\
\text { Each of these variable were assessed in } \\
\text { narrow stance and } 2 \mathrm{~cm} \text { heel separation stance }\end{array}$ & $\begin{array}{l}\text { Fallers had larger CoP movement } \\
\text { area for both stances compared to } \\
\text { non-fallers } \\
\text { Fallers had longer path lengths for } \\
\text { CoP movement in total and for ML } \\
\text { axis for both stances } \\
\text { Fallers had greater amplitudes of } \\
\text { CoP movement in the 2cm heel } \\
\text { separation stance compared to non- } \\
\text { fallers } \\
\circ \quad \text { Fallers had a significantly different } \\
\text { coefficient of sway direction in the } \\
\text { 2cm heel separation stance } \\
\text { compared to non-fallers } \\
\text { Fallers had higher energy content } \\
\text { for all frequencies in the AP } \\
\text { direction for both stances } \\
\circ \quad \text { Fallers had a higher energy content } \\
\text { of sway frequencies } 0-0.5 \mathrm{~Hz} \text { in the } \\
2 \mathrm{~cm} \text { heel separation stance } \\
\circ \quad \text { Fallers had higher energy content of } \\
\text { sway frequencies } 0.5-2 \mathrm{~Hz} \text { and } \\
>2 \mathrm{~Hz} \text { in both the AP and ML axis } \\
\text { in the 2cm heel separation stance } \\
\text { No significant difference: } \\
\text { All other variables }\end{array}$ \\
\hline $\begin{array}{l}\text { Berger et } \\
\text { al. }^{24}\end{array}$ & $\begin{array}{ll}\text { - } & 34 \text { community } \\
& \text { dwelling elderly } \\
& \text { participants } \\
\text { - } & \text { Sedentary individuals } \\
\end{array}$ & $\begin{array}{l}\text { Stood on triangular force platform } \\
\text { in a position with feet adducted at } \\
30^{\circ} \text { and heels separated by } 9 \mathrm{~cm} \\
\text { with their arms at their side and } \\
\end{array}$ & $\begin{array}{ll}\text { - } & \text { CoP trajectory automatically processed in } \\
\text { different ways by specific software program } \\
\text { - } \\
\mathrm{CoG}_{\mathrm{H}} \text { and } \mathrm{CoP}-\mathrm{CoG}_{\mathrm{V}} \text { estimated using the } \\
\text { biomechanical relationship in the frequency }\end{array}$ & $\begin{array}{ll}- & \text { Significant difference: } \\
\circ \quad & \text { Fallers had larger movement areas } \\
& \text { for both } \mathrm{CoP}-\mathrm{CoG}_{\mathrm{V}} \text { and } \mathrm{CoG}_{\mathrm{H}} \\
& \text { compared to non-fallers } \\
\end{array}$ \\
\hline
\end{tabular}




\begin{tabular}{|c|c|c|c|c|}
\hline $\begin{array}{l}\text { Author \& } \\
\text { Date }\end{array}$ & Participants & Task and Equipment Used & Measurement and algorithms employed & Findings \\
\hline & $\begin{array}{l}\text { walking less than } 1 \\
\text { km/day } \\
\text { - } 21 \text { fallers } \\
\circ \quad 6 \text { men/15 women } \\
0 \quad \text { Age } 85.4 \pm 9.3 \\
\text { years } \\
\text { - } 13 \text { Non-fallers } \\
\circ \quad 3 \text { men/10 women } \\
0 \quad \text { Age } 84.3 \pm 6.8 \\
\quad \text { years } \\
\text { No significant } \\
\text { differences between } \\
\text { groups for age, height } \\
\text { or weight of } \\
\text { participants } \\
\text { Faller definition: Self } \\
\text { reported one or more } \\
\text { falls in the last } 12 \\
\text { months that were not } \\
\text { related to a known } \\
\text { intrinsic event }\end{array}$ & $\begin{array}{l}\text { eyes open. } \\
\text { Asked to decrease the amount of } \\
\text { body sway as much as possible } \\
\text { Three trials of } 32 \text { seconds sampled } \\
\text { at } 64 \mathrm{~Hz} \text { and a rest period of } \\
\text { similar duration between each trial } \\
\text { Triangular force platform (pF01, } \\
\text { Equi+, Aix les Bains, France) }\end{array}$ & 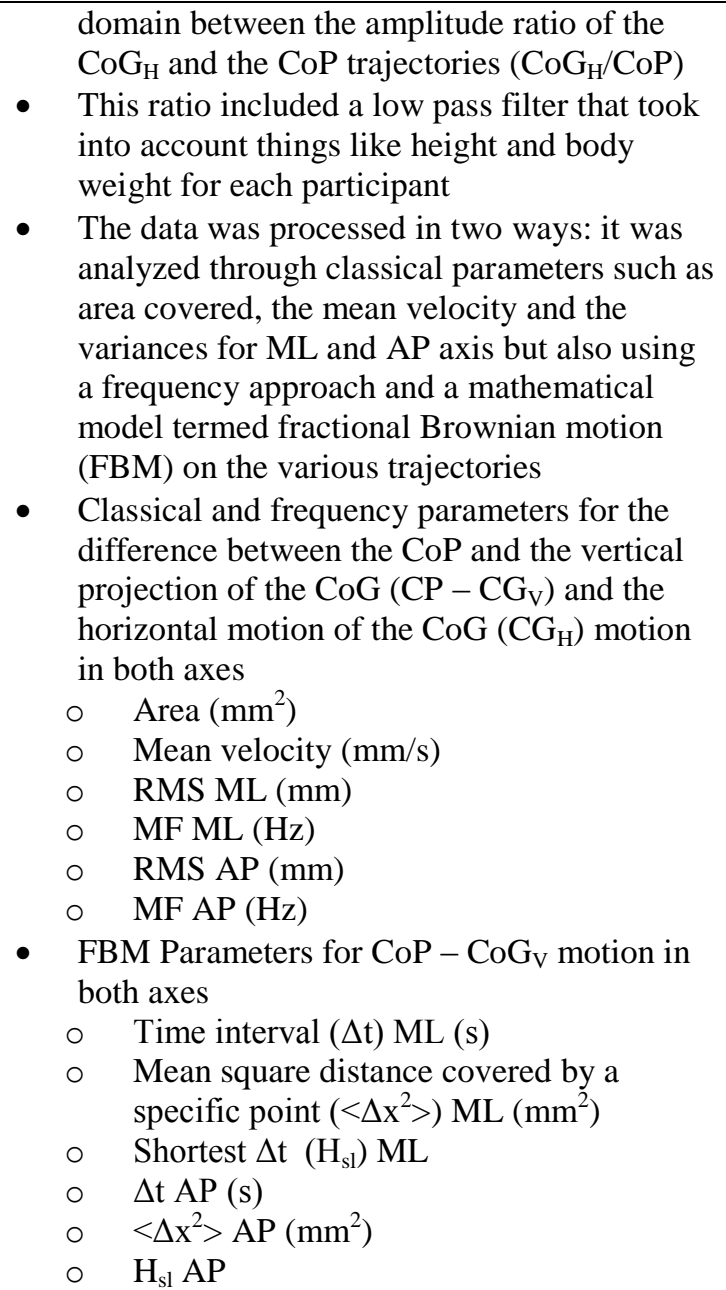 & $\begin{array}{ll} & \text { Fallers had larger mean velocity for } \\
& \mathrm{CoP}-\mathrm{CoG}_{\mathrm{V}} \text { compared to non- } \\
& \text { fallers } \\
& \text { Fallers had larger RMS amplitudes } \\
\text { for both } \mathrm{CoP}-\mathrm{CoG}_{\mathrm{V}} \text { and } \mathrm{CoG}_{\mathrm{H}} \text { in } \\
\text { both the ML and AP axis compared } \\
\text { to non-fallers } \\
\circ \quad \text { Fallers had significantly larger } \\
<\Delta \mathrm{x}^{2}>\text { in both the ML and AP } \\
\text { direction for FBM parameters for } \\
\mathrm{CoP}-\mathrm{CoG}_{\mathrm{V}} \text { compared to non- } \\
\text { fallers } \\
\text { No significant difference } \\
\quad \text { All other variables }\end{array}$ \\
\hline
\end{tabular}




\begin{tabular}{|c|c|c|c|c|}
\hline $\begin{array}{l}\text { Author \& } \\
\text { Date }\end{array}$ & Participants & Task and Equipment Used & Measurement and algorithms employed & Findings \\
\hline & & & $\begin{array}{ll}\text { - } & \text { FBM parameters for } \mathrm{CoG}_{\mathrm{H}} \text { motion in both } \\
\text { axes } & \\
\circ & <\Delta \mathrm{x}^{2}>\mathrm{ML}\left(\mathrm{mm}^{2}\right) \\
\circ & \text { Longest } \Delta \mathrm{t}\left(\mathrm{H}_{\mathrm{ll}}\right) \mathrm{AP} \\
\circ & <\Delta \mathrm{x}^{2}>\mathrm{AP}\left(\mathrm{mm}^{2}\right) \\
\circ & \mathrm{H}_{\mathrm{ll}} \mathrm{AP}\end{array}$ & \\
\hline Lázaro et al. $^{18}$ & $\begin{array}{ll}\text { - } & 226 \text { participants } \\
\text { community dwelling } \\
\text { elderly participants } \\
\text { living in Madrid, } \\
\text { Spain } \\
\text { - } 113 \text { recurrent fallers } \\
\text { - } & 113 \text { controls } \\
85 \% \text { women and mean } \\
\text { age of } 78 \pm 5 \text { years } \\
\text { - Faller definition: Had } \\
\text { undergone two or } \\
\text { more falls in the } \\
\text { previous } 6 \text { months and } \\
\text { had visited their GP or } \\
\text { Geriatrician (self } \\
\text { reported) }\end{array}$ & $\begin{array}{l}\text { Modified Clinical Test for Sensory } \\
\text { Interactions with Balance } \\
\text { (mCTSIB) } \\
\text { - Exact method for test not well } \\
\text { explained } \\
\text { - Performed on Balance Master }{ }^{\circledR} \\
\text { force platform }\end{array}$ & $\begin{array}{l}\text { - Subjects displacement of their } \mathrm{CoG} \text { while } \\
\text { standing }(\% / \mathrm{s})\end{array}$ & $\begin{array}{l}\text { - No significant difference found } \\
\text { between fallers and non-fallers }\end{array}$ \\
\hline $\begin{array}{l}\text { Melzer et } \\
\text { al. }^{25}\end{array}$ & $\begin{array}{ll} & 143 \text { community } \\
\text { dwelling elderly } \\
\text { participants from Beer } \\
\text { Shiva, Israel } \\
\text { - } 19 \text { fallers }\end{array}$ & $\begin{array}{l}\text { Participants stood as still as } \\
\text { possible on a single force plate } \\
\text { with their hands folded behind } \\
\text { their back in both a wide stance } \\
\text { with their eyes open and a narrow }\end{array}$ & $\begin{array}{ll} & \text { COP path length }(\mathrm{cm}) \\
\text { - } & \text { COP velocity } \\
\text { - } & \text { CoP Elliptical area }\left(\mathrm{cm}^{2}\right) \\
\text { - } & \text { CoP ML sway }(\mathrm{cm}) \\
\text { - } & \text { CoP AP sway }(\mathrm{cm})\end{array}$ & $\begin{array}{ll}\text { - } & \text { Significant difference: } \\
& \text { Fallers had longer CoP path lengths } \\
& \text { in narrow stance compared to non- } \\
& \text { fallers } \\
& \text { Fallers had significantly larger }\end{array}$ \\
\hline
\end{tabular}




\begin{tabular}{|c|c|c|c|c|}
\hline $\begin{array}{l}\text { Author \& } \\
\text { Date }\end{array}$ & Participants & Task and Equipment Used & Measurement and algorithms employed & Findings \\
\hline & $\begin{array}{l}\circ \quad \text { Mean age } 78.4 \pm 1.3 \\
\circ \quad 16 \text { males/3 females } \\
\text { - } 124 \text { non-fallers } \\
\circ \quad \text { Mean age } 78.4 \pm \\
\quad 0.53 \\
\quad \quad 91 \text { male/33 female } \\
\quad \text { No significant } \\
\text { differences between } \\
\text { groups in age, height, } \\
\text { weight, foot length, } \\
\text { gender, medication } \\
\text { number, disease } \\
\text { number, incontinence, } \\
\text { dorsiflexion strength, } \\
\text { plantar flexion } \\
\text { strength, knee } \\
\text { extension strength or } \\
\text { knee flexion strength) } \\
\text { Faller definition: At } \\
\text { least } 2 \text { falls in the } \\
\text { previous } 6 \text { months }\end{array}$ & $\begin{array}{l}\text { stance with their eyes open (heels } \\
\text { and toes touching) } \\
\text { - } 20 \text { seconds for each test } \\
\text { Definition of wide stance not } \\
\text { expressed in article }\end{array}$ & $\begin{array}{l}\text { All variables given for both narrow and wide } \\
\text { stances } \\
\text { - For balance measurements repeated measure } \\
\text { analysis of variance (ANOVA) for the two } \\
\text { groups }\end{array}$ & $\begin{array}{ll} & \text { elliptical CoP movement areas in } \\
& \text { narrow stance compared to non- } \\
& \text { fallers } \\
\circ \quad \text { Fallers had greater CoP velocities } \\
\text { in narrow stance compared to non- } \\
\text { fallers } \\
\circ \quad \text { Fallers had significantly larger ML } \\
\text { CoP sway in narrow stance } \\
\quad \text { compared to non-fallers } \\
\text { - No significant difference: } \\
\circ \quad \text { All wide stance variables } \\
\circ \quad \text { All other narrow stance variables }\end{array}$ \\
\hline Merlo et al. ${ }^{26}$ & $\begin{array}{l}\text { - } 130 \text { elderly } \\
\text { participants recruited } \\
\text { from the Memory } \\
\text { Clinic of the Regional } \\
\text { Hospitals of } \\
\text { Mendrisio and } \\
\text { Lugano, Switzerland } \\
\text { - } 67 \text { Non-fallers } \\
\quad \text { Age } 79 \pm 5\end{array}$ & $\begin{array}{l}\text { Pareticipants stood barefoot with } \\
\text { their eyes open on a force plate for } \\
30 \text { seconds } \\
\text { - They were encouraged to maintain } \\
\text { a relaxed position with arms at } \\
\text { their sides } \\
\text { - Their foot position was } \\
\text { standardized by use of a custom } \\
\text { removable device }\end{array}$ & $\begin{array}{ll}\text { - } & \text { AP mean COP position }(\mathrm{mm} \text { from heels) } \\
\text { - } & \text { ML mean COP position }(\mathrm{mm} \text { from heels } \\
\text { - } & \text { Sway mean velocity }(\mathrm{mm} / \mathrm{s}) \\
\text { - } & \text { AP mean velocity }(\mathrm{mm} / \mathrm{s}) \\
\text { - } & \text { ML mean velocity }(\mathrm{mm} / \mathrm{s}) \\
\text { - } & \text { AP RMS displacement }(\mathrm{mm}) \\
\text { - } & \text { ML RMS displacement }(\mathrm{mm})\end{array}$ & $\begin{array}{l}\text { - Significant difference: } \\
\circ \quad \text { Fallers had a greater AP mean CoP } \\
\text { position compared to non-fallers } \\
\text { and recurrent fallers } \\
\circ \text { Recurrent fallers had larger area of } \\
\text { 95\% confidence ellipse compared } \\
\text { to non-fallers } \\
\text { - No significant difference: } \\
\text { O ML mean COP position }\end{array}$ \\
\hline
\end{tabular}




\begin{tabular}{|c|c|c|c|c|}
\hline $\begin{array}{l}\text { Author \& } \\
\text { Date }\end{array}$ & Participants & Task and Equipment Used & Measurement and algorithms employed & Findings \\
\hline & $\begin{array}{l}\quad 43 \% \text { male } \\
\text { - } 45 \text { Fallers } \\
\circ \quad \text { Age } 79 \pm 6 \\
\circ \quad 42 \% \text { male } \\
\text { - } 18 \text { Recurrent Fallers } \\
\circ \quad \text { Age } 81 \pm 6 \\
\circ \quad 22 \% \text { male } \\
\text { - Faller definition: One } \\
\text { or two falls in the last } \\
\text { year } \\
\text { Recurrent faller } \\
\text { definition: More than } \\
\text { two falls in the last } \\
\text { year }\end{array}$ & $\begin{array}{l}\text { - The distance between the centre of } \\
\text { their heels ranged from } 14 \text { to } 16 \\
\mathrm{~cm} \text { depending on foot size and the } \\
\text { angle between each foot and the } \\
\text { AP direction was } 10^{\circ} \\
\text { There was a visual target placed at } \\
\text { eye level } 1.5 \mathrm{~m} \text { away } \\
\text { One piezoelectric force plate was } \\
\text { used in Mendrisio } \\
\text { One strain gauge force plate was } \\
\text { used in Lugano }\end{array}$ & $\begin{array}{l}\text { - } \\
\text { - } \\
\text { Data of collected using bioware software at a } \\
\text { sampling frequency of } 100 \mathrm{~Hz} \\
\text { - Mean value tested using Kruskal-Wallis test } \\
\text { - } \quad \text { Between group comparisons completed using } \\
\text { Mann-Whitney test } \\
\text { - Comparisons between proportions were } \\
\text { carried out by mean of the Fisher Exact test }\end{array}$ & $\begin{array}{ll} & \text { Sway mean velocity } \\
\circ & \text { AP mean velocity } \\
\circ & \text { ML mean velocity } \\
\circ & \text { AP RMS displacement } \\
\circ & \text { ML RMS displacement }\end{array}$ \\
\hline Park et al. ${ }^{27}$ & $\begin{array}{ll} & 29 \text { community } \\
& \text { dwelling elderly } \\
& \text { participans from four } \\
& \text { local senior welfare } \\
& \text { centers } \\
\text { - } & 3 \text { men/26 women } \\
\text { - } & \text { Mean age } 78.9 \pm 4.69 \\
& \text { years } \\
\text { - } & 8 \text { Fallers } \\
\text { - } & 21 \text { Non-fallers } \\
\text { - } & 65 \text { and over } \\
\text { - } & \text { Faller definition: Self } \\
& \text { reported fall in the last } \\
& \text { year } \\
\text { - } & \text { Fall Definition: An } \\
\end{array}$ & 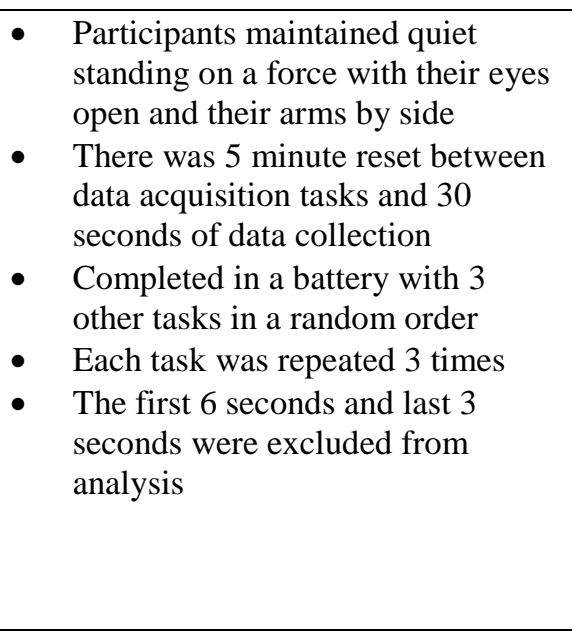 & $\begin{array}{l}\text { CoP range and CoP displacement in the AP } \\
\text { and ML axis } \\
\text { All data analyzed using the Mann-Whitney U } \\
\text { test }\end{array}$ & $\begin{array}{ll} & \text { No significant difference: } \\
\circ & \text { CoP range in the ML plane } \\
\circ & \text { CoP range in the AP axis } \\
\circ & \text { CoP distance in the ML axis } \\
\circ & \text { CoP distance in the AP axis }\end{array}$ \\
\hline
\end{tabular}




\begin{tabular}{|l|l|l|l|l|}
\hline Author \& & Participants & Task and Equipment Used & Measurement and algorithms employed & Findings \\
\hline Date & $\begin{array}{l}\text { event causing a person } \\
\text { to rest unintentionally } \\
\text { on the ground or other } \\
\text { lower level not due to } \\
\text { any intentional } \\
\text { movement, a major } \\
\text { intrinsic event, or } \\
\text { extrinsic force }\end{array}$ & & \\
\hline
\end{tabular}

Notes. cm, centimeter; ML, mediolateral; mm, millimetres; s, seconds; CoP, centre of pressure; Anteroposterior, AP; Hz, Hertz; CoG, centre of gravity; RMS, root mean

square; MF, median frequency. 
Table 4 - Data extraction table for stairs

\begin{tabular}{|c|c|c|c|c|}
\hline $\begin{array}{l}\text { Author \& } \\
\text { Date }\end{array}$ & $\begin{array}{l}\text { Participants \& faller } \\
\text { definition }\end{array}$ & Task and Equipment Used & Measurement and Algorithms Employed & Findings \\
\hline Lázaro et al. ${ }^{18}$ & $\begin{array}{ll}\text { - } & 226 \text { participants } \\
\text { community dwelling } \\
\text { elderly participants } \\
\text { living in Madrid, Spain } \\
\text { - } & 113 \text { recurrent fallers } \\
\text { - } & 113 \text { controls } \\
\text { - } & 85 \% \text { women and mean } \\
\text { age of } 78 \pm 5 \text { years } \\
\text { - } & \text { Faller definition: Had } \\
\text { undergone two or more } \\
\text { falls in the previous } 6 \\
\text { months and had visited } \\
\text { their GP or Geriatrician } \\
\text { (self reported) }\end{array}$ & $\begin{array}{ll}- & \text { Step up and down from a step } \\
\text { - } & \text { Exact method for test not well } \\
\text { explained } \\
\text { - } \\
\text { Performed on a Balance } \\
\text { Master® force platform }\end{array}$ & $\begin{array}{l}\text { Force exerted through the participants legs } \\
\text { expressed as a percentage of their BW } \\
\text { Results reported: Lift-up index (left and right } \\
\text { leg) and impact index (left and right leg) }\end{array}$ & $\begin{array}{l}\text { - Significant difference: } \\
\quad \text { Fallers had lower lift-up indexes for } \\
\text { each leg compared to non-fallers } \\
\text { - } \quad \text { No significant difference: } \\
\circ \quad \text { Impact index for each leg }\end{array}$ \\
\hline
\end{tabular}

Notes. BW, body weight; GP, general practitioner. 
Table 5 - Quality Assessment of Included Articles ( $C D=$ Cannot determine, NA = Not applicable, NR = Not reported)

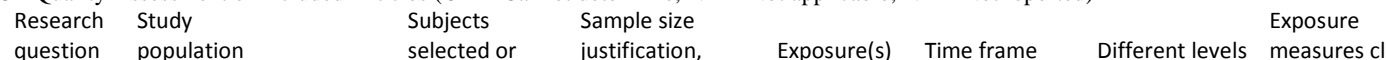
or clearly Participation recruited from power description of interest sufficient for of exposure defined, valid, objective specified rate of the same or or variance and measured outcome to be examined in reliable and $\begin{array}{llllll}\begin{array}{l}\text { clearly } \\ \text { stated }\end{array} \quad \begin{array}{lll}\text { and } \\ \text { defined }\end{array} & \begin{array}{l}\text { eligible } \\ \text { persons } \geq 50 \% \text { population }\end{array} & \begin{array}{l}\text { effect estimates } \\ \text { provided }\end{array} & \begin{array}{l}\text { prior to } \\ \text { outcome(s) }\end{array} & \begin{array}{l}\text { shown if } \\ \text { present }\end{array}\end{array}$ relation to implemented

Outcome

Exposure(s) measures clearly Outcome measured defined, valid,

Outcome

Loss of follow confounding

\begin{tabular}{|c|c|c|}
\hline Aoki et al. ${ }^{22}$ & $\checkmark$ & $\checkmark$ \\
\hline Bauer et al. ${ }^{23}$ & $\checkmark$ & $x$ \\
\hline Berger et al. ${ }^{24}$ & $\checkmark$ & $x$ \\
\hline Cheng et al. ${ }^{14}$ & $\checkmark$ & $x$ \\
\hline Ejupi et al. ${ }^{15}$ & $\checkmark$ & $\checkmark$ \\
\hline Ejupi et al. ${ }^{16}$ & $\checkmark$ & $\checkmark$ \\
\hline \|luz et al. ${ }^{17}$ & $\checkmark$ & $x$ \\
\hline Lázaro et al. ${ }^{18}$ & $\checkmark$ & $\checkmark$ \\
\hline Liang et al. ${ }^{19}$ & $\checkmark$ & $x$ \\
\hline Melzer et al. ${ }^{25}$ & $\checkmark$ & $x$ \\
\hline Merlo et al. ${ }^{26}$ & $\checkmark$ & $\checkmark$ \\
\hline Panzer et al. ${ }^{20}$ & $\checkmark$ & $\checkmark$ \\
\hline Park et al. ${ }^{27}$ & $\checkmark$ & $x$ \\
\hline Yamada et al..$^{21}$ & & \\
\hline
\end{tabular}

$N R$
$N R$
$N R$
$N R$
$N R$
$N R$
$N R$
$N R$
$N R$
$N R$
$N R$
$N R$
$N R$

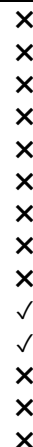

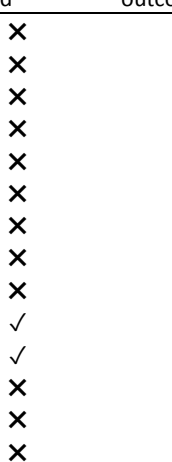

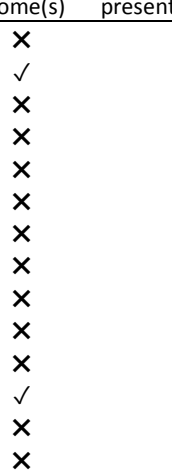

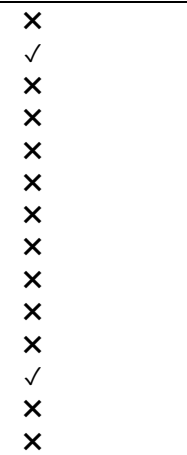

$x$
$v$
$x$
$x$
$x$
$x$
$x$
$x$
$x$
$x$
$v$
$v$
$x$
$x$

mplemented

blinded to up after variable consistently

NA
$\times$
NA
NA
NA
NA
$\times$
NA
NA
NA
NA
$\checkmark$
NA
NA

NR
$N R$
$N R$
$N R$
$N R$
$N R$
$N R$
$J$
$N R$
$N R$
$N R$
$N R$
$N R$
$N R$
$N R$

$\leq 20 \%$ djusted for

Percentage

$\mathrm{NA}$
$\checkmark$
$50 \%$

NA

$x$

